IRA-International Journal of Education \&

Multidisciplinary Studies

ISSN 2455-2526; Vol.11, Issue 01 (April, 2018)

Pg. no. 13-31.

Institute of Research Advances

http://research-advances.org/index.php/IJEMS

\title{
Risks Management for Liquid Waste Disposal Area in the Khartoum Refinery- Sudan
}

\author{
Mohieldeen M. A. Ahmed ${ }^{1}$, Osman M. M. Ali ${ }^{2}$, Muzmmel M.M. Ibrahim ${ }^{3 \#}$, Omer M.A. Al \\ Ghabshawi $^{4}$ \\ ${ }^{1,2}$ University of Khartoum, Institute of Environmental Studies, Ministry of Higher Education and Scientific \\ Research, Khartoum, Sudan. \\ ${ }^{3}$ University of Khartoum, Faculty of Agriculture, Dept. of Soil and Environmental Science, Ministry of \\ Higher Education and Scientific Research, Khartoum, Sudan. \\ ${ }^{4}$ Sudan University of Science and Technology, Faculty of Petroleum Engineering, Ministry of Higher \\ Education and Scientific Research, Khartoum, Sudan.
}

\#corresponding author.

Type of Review: Peer Reviewed.

DOI: http://dx.doi.org/10.21013/jems.v11.n1.p2

\section{How to cite this paper:}

Ahmed, M.A.M., Ali, O.M.M., Ibrahim, M.M.M., Ghabshawi, O.M.A.A. (2018). Risks Management for Liquid Waste Disposal Area in the Khartoum Refinery-Sudan. IRA International Journal of Education and Multidisciplinary Studies (ISSN 2455-2526), 11(1), 13-31.doi: http://dx.doi.org/10.21013/jems.v11.n1.p2

(C) Institute of Research Advances.

\section{(cc) BY-NC}

This work is licensed under a Creative Commons Attribution-Non Commercial 4.0 International License subject to proper citation to the publication source of the work.

Disclaimer: The scholarly papers as reviewed and published by the Institute of Research Advances (IRA) are the views and opinions of their respective authors and are not the views or opinions of the IRA. The IRA disclaims of any harm or loss caused due to the published content to any party.

Institute of Research Advances is an institutional publisher member of Publishers Inter Linking Association Inc. (PILA-CrossRef), USA. The institute is an institutional signatory to the Budapest Open Access Initiative, Hungary advocating the open access of scientific and scholarly knowledge. The Institute is a registered content provider under Open Access Initiative Protocol for Metadata Harvesting (OAI-PMH).

The journal is indexed \& included in WorldCat Discovery Service (USA), CrossRef Metadata Search (USA), WorldCat (USA), OCLC (USA), Open J-Gate (India), EZB (Germany) Scilit (Switzerland), Airiti (China), Bielefeld Academic Search Engine (BASE) of Bielefeld University, Germany, PKP Index of Simon Fraser University, Canada. 


\begin{abstract}
This study focused on evaluating the procedures of risk management associated with disposal of oil wastewater at Gaili area, Khartoum north, Sudan. Approaches used in this study. Research tools conducted were Interviews, sampling and analysis report interpretation, aerial photographs analysis \& topographic modeling analysis for the Gaili area. The study of risk management is conducted for oily wastewater disposal at Gaili area and analyzed current activities of the Khartoum refinery, petrochemical plant, Garri power plant, fuel terminals and the gathered data. The Study found that the selection of the site of the wastewater area was improper, the construction specification of the oily waste water area was not following the international standards and the final disposal of the generated sludge is not following the international environmental conventions. The study found that the wastewater disposal area might have huge probability of impacting the surrounding environment, and severe impacts will be on the groundwater, soil, surrounding water courses and the quality of the air in Gaili area will be affected by oily wastewater disposal. The study recommended establishing an environmental monitoring program for the wastewater activities, and to conduct an environmental site assessment of the area and adopt the remediation plan developed according to the developed data, to construct a new sedimentation lagoon according to international standard and to provide a bioremediation unit to treat the generated sludge.
\end{abstract}

Key words: Environment, Waste Disposal, Risk Management

\title{
1. Introduction:
}

Khartoum refinery is a complex refinery, design typically to process Sudanese crude or Nile blended. Total capacity of the refinery is 100,000 barrels per day. There is a new extension with capacity of 20,000 barrel per day. The main product of the refinery is motor gasoline unleaded with high octane number (91.5), liquefied petroleum gas (LPG), gas oil and turbine jet fuel. The refinery operates continuously for 24 hours.[1]

The Khartoum refinery was constructed in 1999 and it is located 15 kilometers north east of Gaili town (70 Km) North of Khartoum in a semi rocky desert land about 12 kilometers from Nile River. There are two valleys on both sides of the refinery flow direct to the river Nile.

Gaili Area $(70 \mathrm{Km})$ North of Khartoum as the main Investment for Sudan which costs about (7) Billion Dollars including (Khartoum refinery Co-KRC, petrochemicals plant, Gaili fuel terminals, Garri Power Plant) and recently Garri free zone is attached to the area. [2]

The aim of this paper is to study the risks associated with the waste disposal for petroleum liquid from KRC and the contractors working under it and assess the negative impact on neighboring village located nearby and probability of affecting by associated hazards. Petroleum liquid waste treatment plant is the main environment protection facility to degrade pollutants in water. The oily water from processing unit into wastewater treatment plant will be pumped by oily water pump into oil separator, first stage and second stage floating pools to remove surface oil and some other pollutants. Then enter biological pool to remove phenols containing in wastewater.

Risk Concept: Understanding risk is a complex, multidisciplinary endeavor, there are many dimensions, technical, economic, social, political [3], and these dimensions are not universal and are often divergent [4]. WHO defines risk as "the probability of an adverse effect in an organism, system or sub-population caused under specified circumstances by exposure to an agent" [5]. Environmental risk assessment as outlined is a systematic procedure for considering the potential effects of proposed new projects on the surrounding environment [6]

The essential components of risk are knowledge of the environmentally relevant features of the proposed operation [7] (e.g. emissions, effluents, noise) [8] and understanding of the sensitivity of the receiving environment [9]. The scope of the required assessment should be first defined, the impact of various factors (noise, effluents etc.) can then be assessed. [10] Or the process of considering at the planning stages the potential effects of a proposed new project on the surrounding environment. [11].

Khartoum Refinery Company limited built three lagoons to treat wastewater from treatment plant and production wastewater. Wastewater in lagoon would not be discharged or leak but vaporized. The total flow rate is 300 ton/hour with a dimension three ponds for each $(650 \times 420 \times 2.2) \mathrm{m}^{3}$. Active sludge, scum and sludge from wastewater treatment plant dewatered in concentrator and sent into dehydrator by screw pump. By dehydration water content been $84-88 \%$ and volume reduced 20 times. Slope oil from sampling of all processing units and storing tanks sent 
into sedimentation tanks. Other invaluable solids buried in a specified plant about 12 Kilometer far away from the refinery to the eastern side.

The proper selection of site is very crucial for petroleum refineries. The geological hydro-geological, topographical and climatologically factors must be considered. The site location should be chosen where the wastewater area would cause the least environmental and social impacts and the impacts must be assessed prior to the construction and the control measures must be identified and adopted and the facilities design and best operational management practices are needed to minimize the associated risks. Environmental investigations should be used to assess the surrounding land usage, local climate factors, site topography, identification of sensitive water resources, soil strata, surface water and groundwater movement, and the site's land-use history. Industrial wastewater facilities should not be located in areas with a near surface water table that are prone to waterlogging or may be flooded during a 100year average recurrence interval (ARI) event. This includes land which is seasonally wet, requires artificial drainage or diversion of natural watercourses, or where construction and disposal will affect sensitive waters.

Pollution is defined as an undesirable change in the physical, chemical, or biological characteristics of the air, water, or land that can harmfully affect health survival or activities of humans or other living organisms. Pollution arises from the presence of materials that are foreign to the body of air, water and land. [12].

Petroleum liquid waste practices may pose significant risks to sensitive water resources, contaminate the soil of the surrounding areas and there are several severe impacts on the surrounding residents from hydrocarbons evaporation and migration by wind, as well as to the workers of the refinery. [13].

The impacts that may occur when liquid wastes are discharged include petroleum hydrocarbons, heavy metals, surfactants, toxins and salts, which may pollute receiving waters rendering them unsuitable as a water supply or pose a threat to aquatic life. Some liquid wastes are volatile or release toxic gases. In receiving waters, excessive nutrients can lead to algal blooms, oxygen deficits and increase color and turbidity. Liquid wastes are also recorded as contaminant for underground water.

Refining is a very important step in oil production. Water is used for several purposes at different stages of petrol refining and appreciable amount of wastewater is left behind. Treatment and there upon disposal after the treatment - pollution of water resources nearby is expected. The evolution carbon compounds gases form the refinery will also pollute water resources. Regarding groundwater contamination, the most significant effect generally occurs in the uppermost aquifer, which is frequently shallow and used for domestic purposes. Oil pollution hazards do not stop at this point.

The treatment techniques can be physical, chemical or biological. The waste treatment unit for water should be designed in a modified way by collection of waste water and separation for alkali and acidic water to be neutralize, then skimming of oil from the water. This waste water should the pass into biochemical unit for further treatments to get rid of the polluted materials.

The major aim of treating hazardous wastes is to modify the physical and chemical properties of the wastes so that they will have less or no impacts on health and environment or to render it more amenable for final disposal. The main sources of pollutants form petroleum production are; wastewater containing oil, phenols, and inorganic minerals including sulfates.

It occurs at the cleaning-by -water process. Sulfates, ammonia, and phenols as well as low compounds are left after the cooling of steam passing through the distillation towers, alkaline waste that contains sulfates is produced from caustic soda cleansing of petroleum product and acidic wastes are produced from various refining operation. [14]

\section{Materials and Methods:}

The methodology adopted in this study was by conducting a site reconnaissance to review the environmental conditions of the study area and as part of the risk study activities several interviews were conducted with the key personnel of the KRC park and workers of the adjacent areas, as well as interviews with the people who are living in the surrounding areas. Several photographs were collected from the site as shown in Plate (1) and interpreted to study the negative impacts on the area. 
The study analysed the available data for the waste water chemical and physical analysis of the nearby monitoring well to the waste water area as shown in table (1), there is no available data for the waste water analysis as this practice is not required by the health and safety and environmental procedures adopted by the management of the KRC. The chemical and physical results was compared with the tables of Royal Commission of Jubail and Yanbu Environmental Regulations 2015 issued by the Environmental Protection and Control department, the study team took this standard as a benchmark to compare to due to the lack of any related regulation adopted by the Sudanese government.

The study team created a topographical map for the area to analyse the probability of risks associated with flood zones areas and the consequences of any overflow occurring in the waste water area. The topographical maps are shown in figure (1) and (2).

The methodology also analysed the aerial photographs available for the area, to replace the lack of information regarding the history of disposal areas in the KRC facility. The aerial photographs were obtained from google earth pro and shown in Aerial Photos (01) to (06).[15]

The above collected information and its interpretation were to identify the associated risks of the wastewater disposal area as an environmental aspect to identify the environmental impacts.

Table (1) Chemical \& Physical Analysis of Water Well at EL Gaili Area

\begin{tabular}{|l|c|c|c|}
\hline \multicolumn{1}{|c|}{ Parameter } & Nilab Bore & Main Bore & $\begin{array}{c}\text { RC Maximum } \\
\text { Allowable }\end{array}$ \\
\hline Turbidity & Nil & 0.5 & 5 \\
\hline PH & 7.5 & 7.5 & $6-8.4$ \\
\hline Iron Total & Nil & Nil & 5 \\
\hline Nitrate & Nil & Nil & 10 \\
\hline Ammonia & 0.4 & 0.4 & 3 \\
\hline Fluoride & 0.2 & 0.15 & 15 \\
\hline Chromium & NIL & Nil & 0.5 \\
\hline Copper & 0.4 & 0.4 & 0.5 \\
\hline Manganese & Nil & Nil & 1.0 \\
\hline Phosphate & Nil & Nil & 2.0 \\
\hline Sulphide & Nil & Nil & 0.1 \\
\hline TSS & Nil & Nil & 40 \\
\hline
\end{tabular}

Source: (MCC at Gaili Area/ SPC - 2016) [16]

The above analysis does not contain the analysis of oil and grease, PAH, dissolved Oxygen, Total Organic Carbon, MTBE, TBA, benzene and BTEX. Which are the main impacts expected from in the oil refineries and petrochemical plants.

Notes: Estimated Flow Rate for Water Well: $40-60 \mathrm{~m}^{3} / \mathrm{hr}$ 
Khartoum Refinery Company Industrial Waste Water Lagoon at Gaili Area
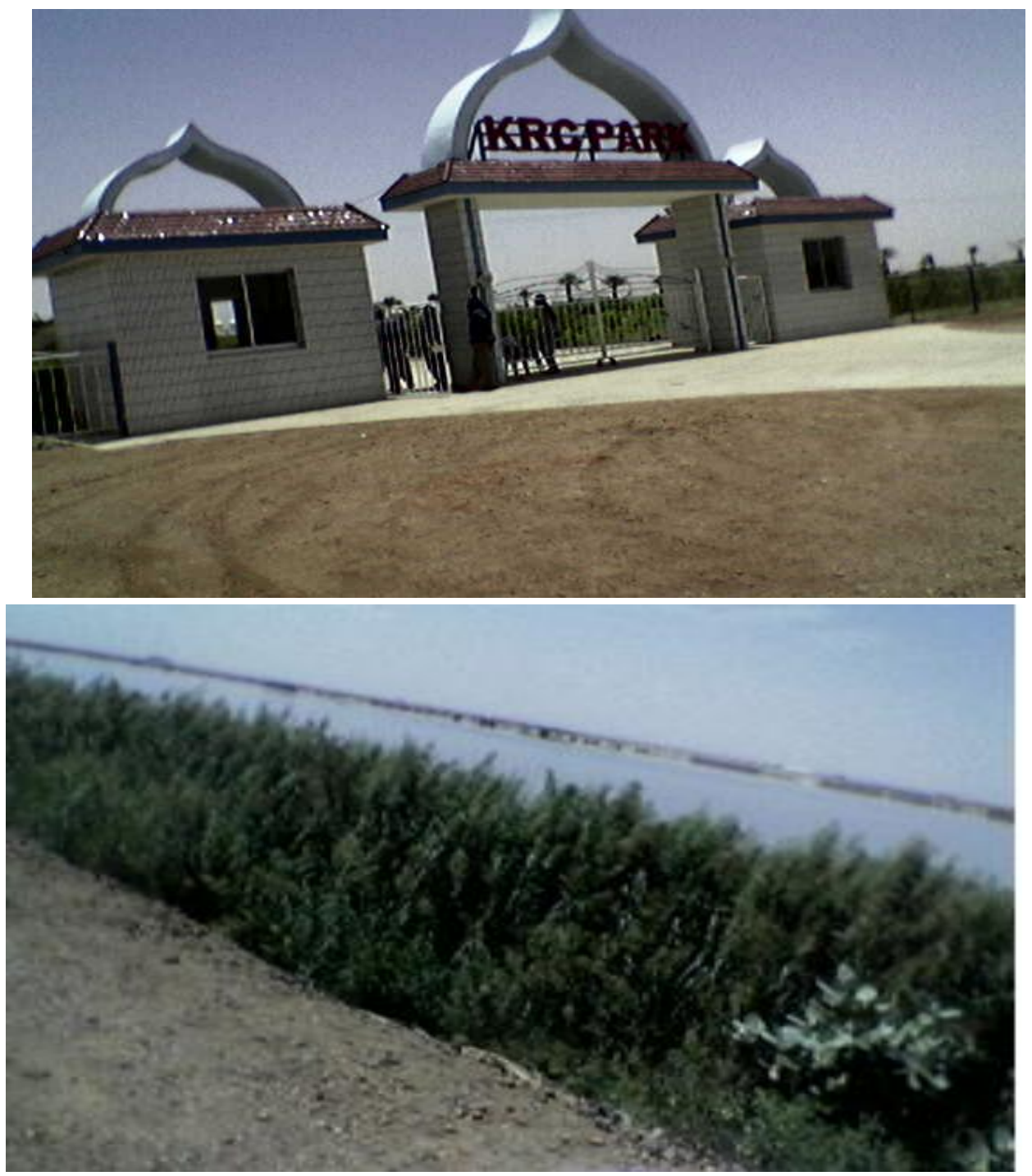

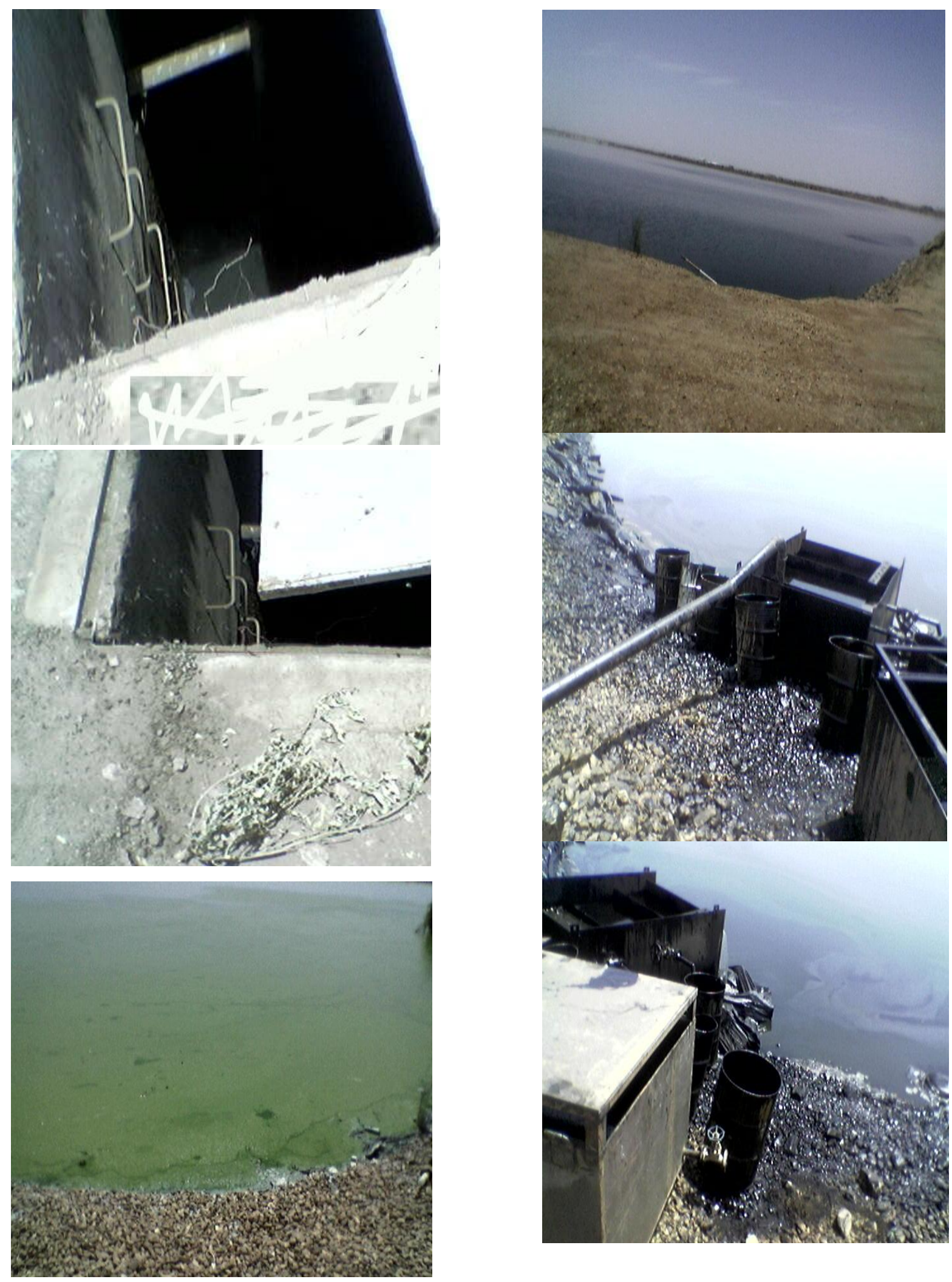

Plate (1) Khartoum Refinery Company Industrial Waste Water Lagoon at Gaili Area 


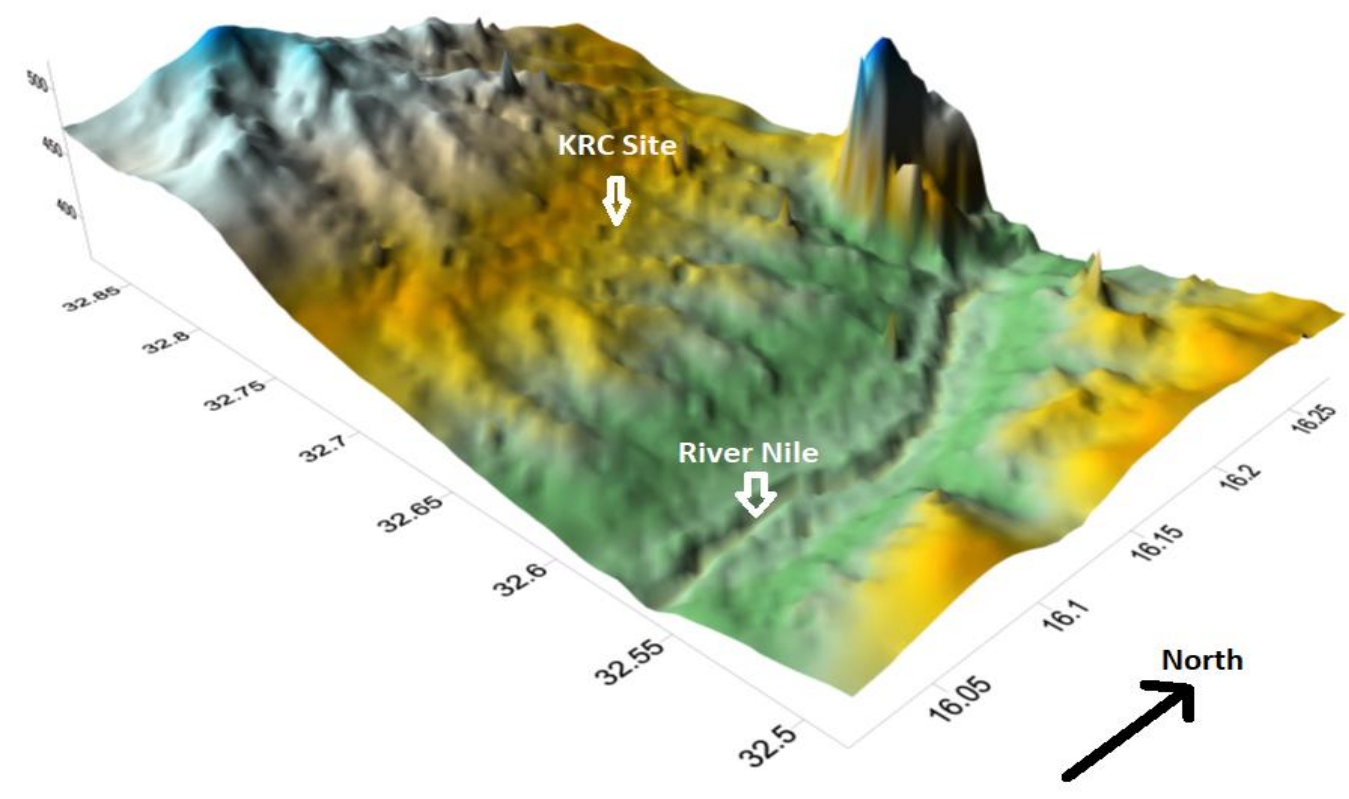

Figure (1): Gaili Area Topographical Model (Created January 2018)

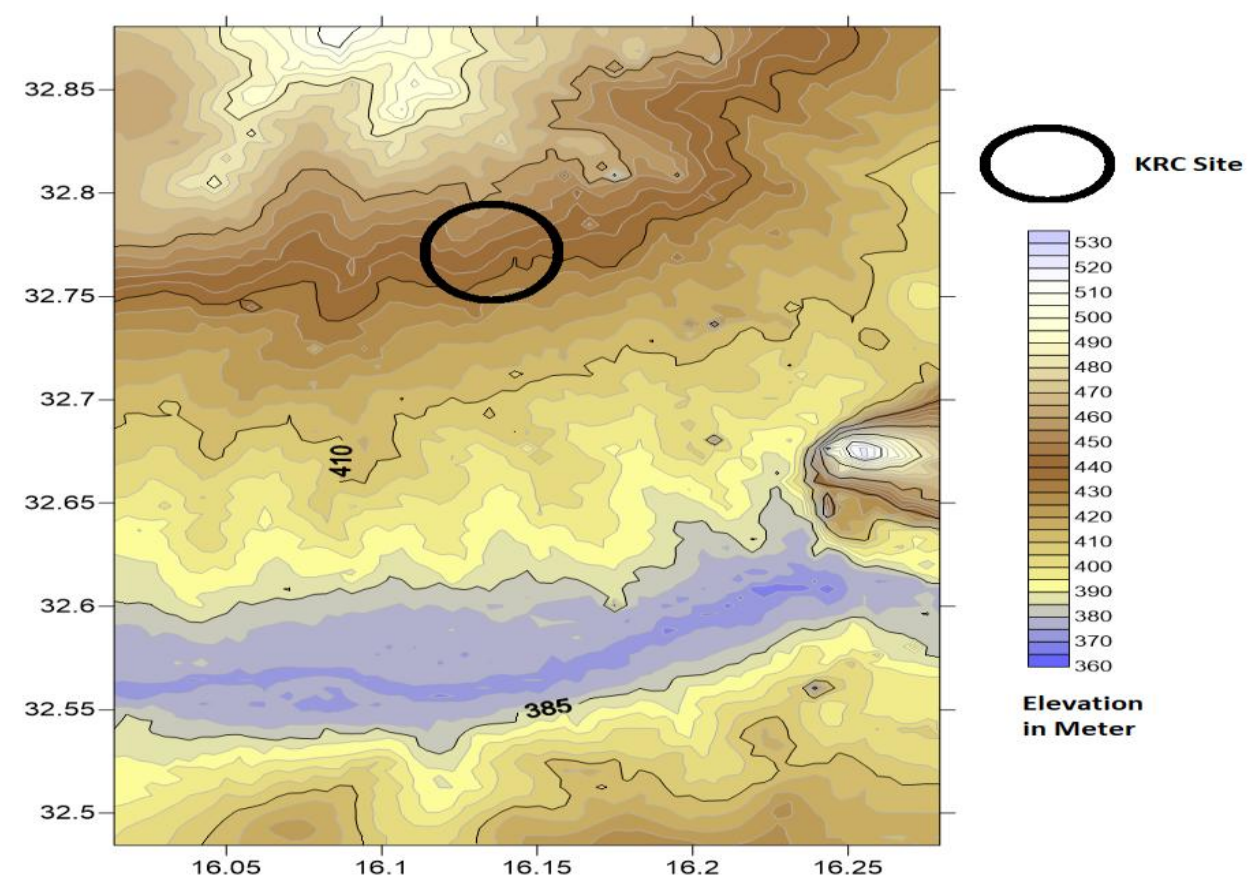

Figure (2): Gaili Area Topographical Model (Created January 2018) 


\section{Weather in Khartoum Refinery Area:}

In Khartoum, the summers are short, sweltering, arid, and partly cloudy and the winters are short, warm, dry, windy, and mostly clear. Over the course of the year, the temperature typically varies from $18^{\circ} \mathrm{C}$ to $41^{\circ} \mathrm{C}$ and is rarely below $14^{\circ} \mathrm{C}$ or above $44^{\circ} \mathrm{C}$.

\section{Climate Summary:}

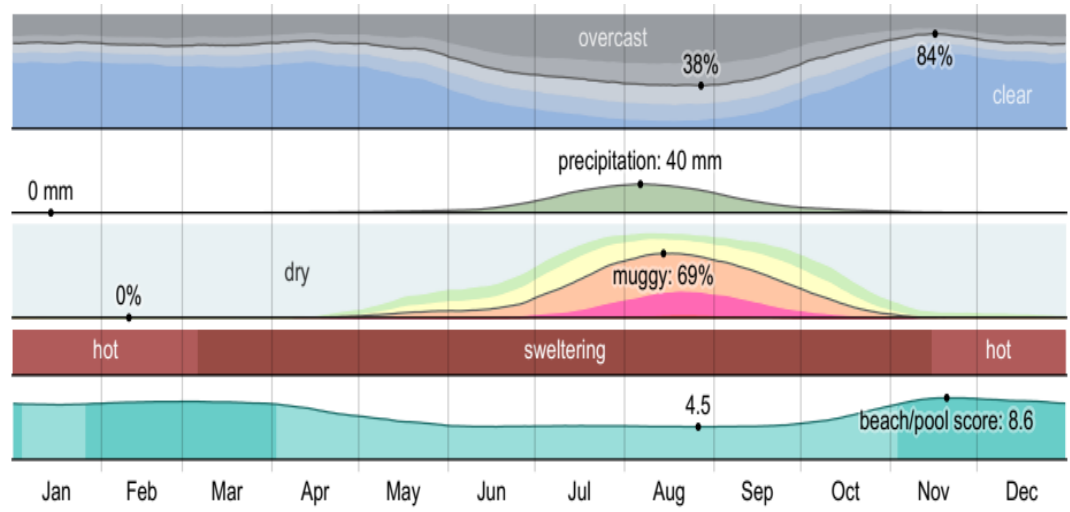

Figure (3) Climate at Gaili Area

\section{Temperature}

The hot season lasts for 2.8 months, from April 10 to July 4, with an average daily high temperature above $39^{\circ} \mathrm{C}$. The hottest day of the year is May 25, with an average high of $41^{\circ} \mathrm{C}$ and low of $30^{\circ} \mathrm{C}$. The cool season lasts for 2.2 months, from December 7 to February 13, with an average daily high temperature below $32^{\circ} \mathrm{C}$.

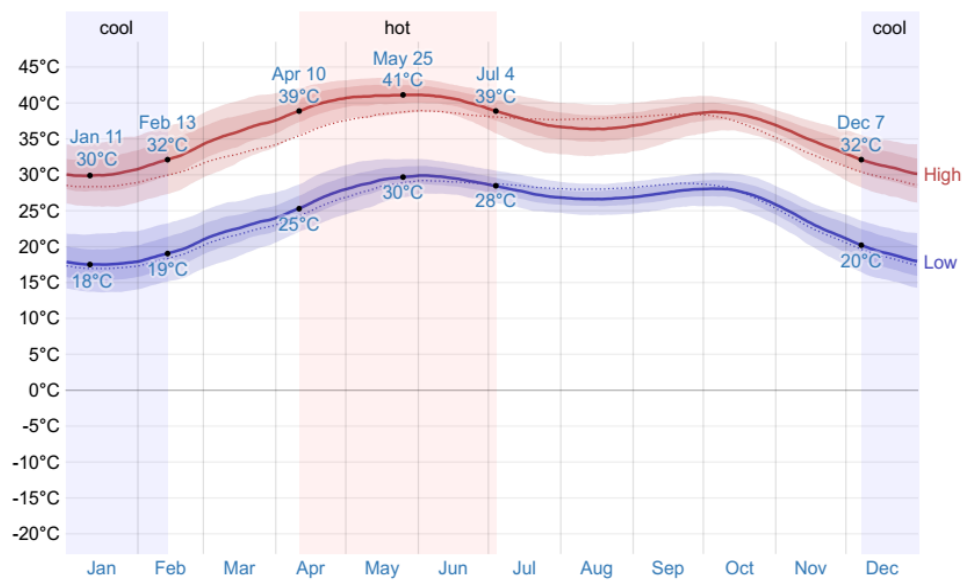

Figure (4): Average High and Low Temperature

The daily average high (red line) and low (blue line) temperature, with 25th to 75th and 10th to 90th percentile bands.

The thin dotted lines are the corresponding average perceived temperatures. The figure below shows you a compact characterization of the entire year of hourly average temperatures. The horizontal axis is the day of the year, the vertical axis is the hour of the day, and the color is the average temperature for that hour and day. 


\section{Clouds:}

In Khartoum, the average percentage of the sky covered by clouds experiences significant seasonal variation over the course of the year.

The clearer part of the year in Khartoum begins around October 4 and lasts for 8.0 months, ending around June 5 . On November 16, the clearest day of the year, the sky is clear, mostly clear, or partly cloudy $84 \%$ of the time, and overcast or mostly cloudy $16 \%$ of the time.

The cloudier part of the year begins around June 5 and lasts for 4.0 months, ending around October 4. On August 27, the cloudiest day of the year, the sky is overcast or mostly cloudy $62 \%$ of the time, and clear, mostly clear, or partly cloudy $38 \%$ of the time.

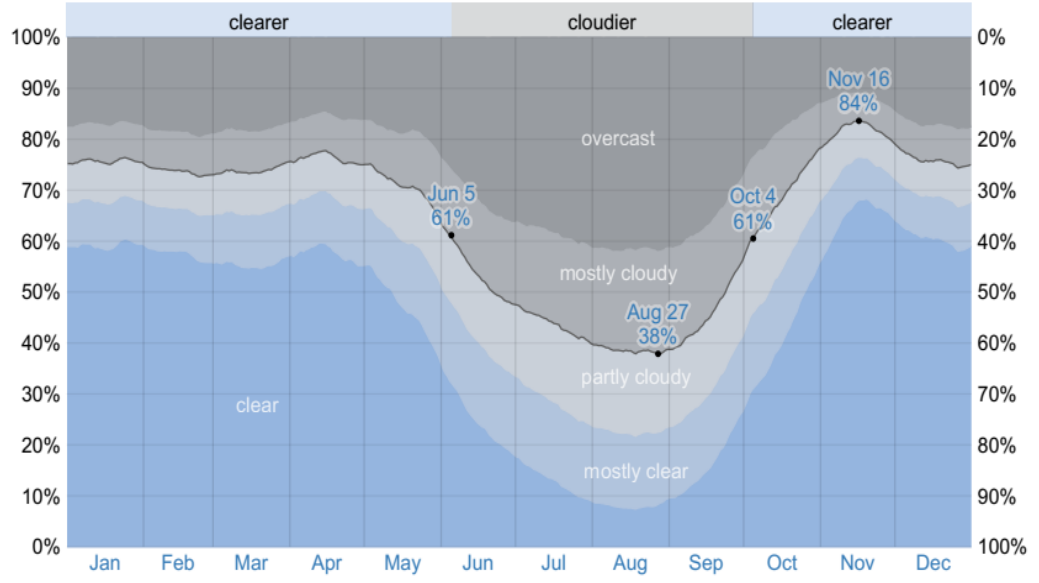

Figure (5): Cloud Cover Categories

\section{Precipitation}

A wet day is one with at least 1 millimeter of liquid or liquid-equivalent precipitation. The chance of wet days in Khartoum varies throughout the year. The wetter season lasts 2.2 months, from July 5 to September 11 , with a greater than $14 \%$ chance of a given day being a wet day. The chance of a wet day peaks at $28 \%$ on August 9.The drier season lasts 9.8 months, from September 11 to July 5. The smallest chance of a wet day is $0 \%$ on January 1.Among wet days, we distinguish between those that experience rain alone, snow alone, or a mixture of the two. Based on this categorization, the most common form of precipitation throughout the year is rain alone, with a peak probability of $28 \%$ on August 9.

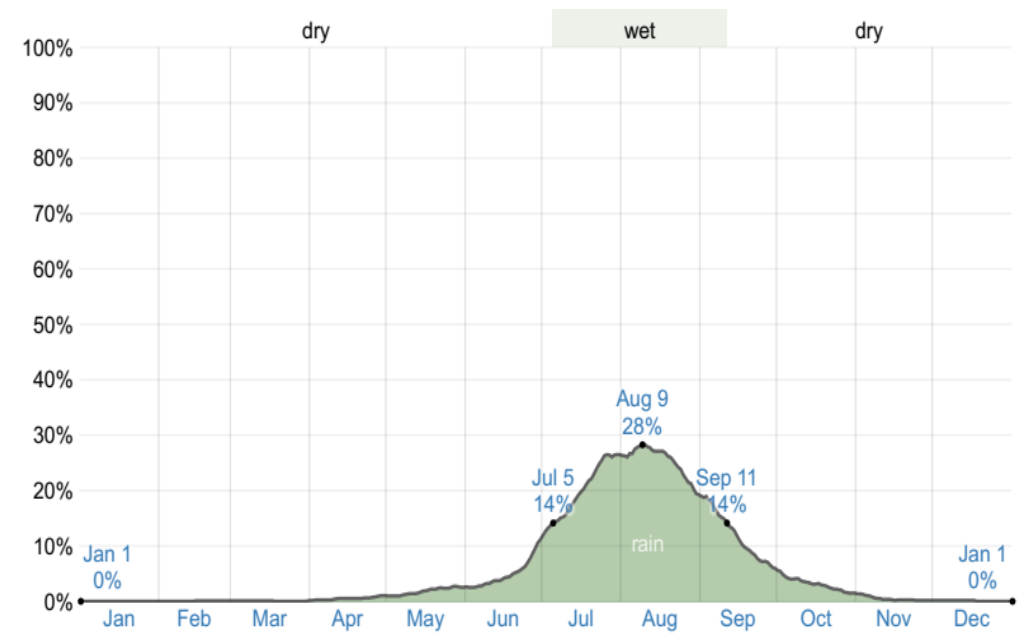

Figure (6): Daily Chance of Precipitation 


\section{Rainfall}

To show variation within the months and not just the monthly totals, we show the rainfall accumulated over a sliding 31-day period centered around each day of the year. Khartoum experiences some seasonal variation in monthly rainfall. The rainy period of the year lasts for 2.8 months, from June 26 to September 20, with a sliding 31-day rainfall of at least 13 millimeters. The most rain falls during the 31 days centered around August 7, with an average total accumulation of 40 millimeters. The rainless period of the year lasts for 9.2 months, from September 20 to June 26. The least rain falls around January 2, with an average total accumulation of 0 millimeters.

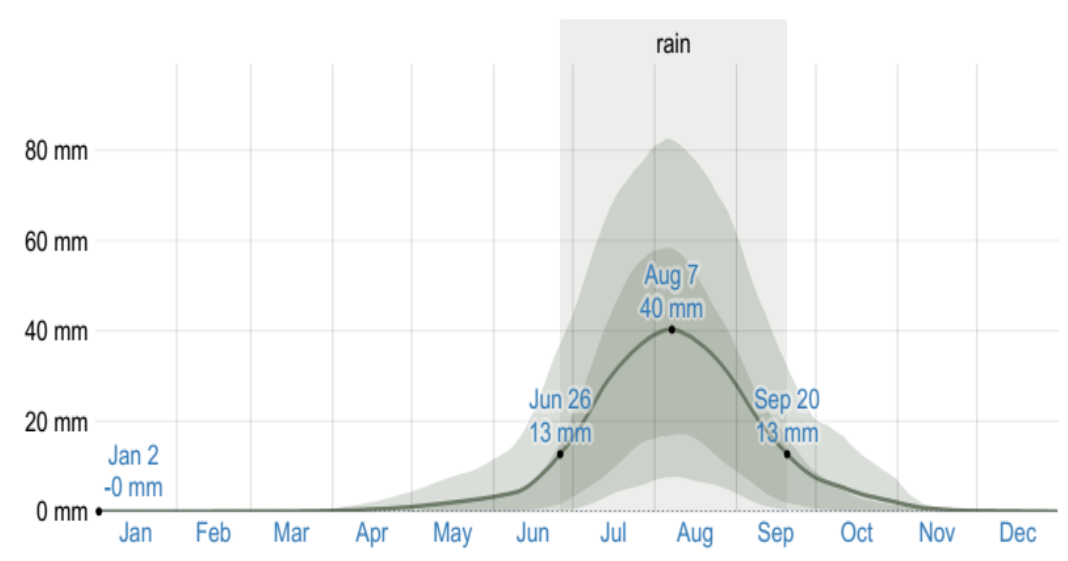

Figure (7): Average Monthly Rainfall

The average rainfall (solid line) accumulated over the course of a sliding 31-day period centered on the day in question, with 25th to 75th and 10th to 90th percentile bands. The thin dotted line is the corresponding average liquid-equivalent snowfall.

\section{Wind}

This section discusses the wide-area hourly average wind vector (speed and direction) at 10 meters above the ground. The wind experienced at any given location is highly dependent on local topography and other factors, and instantaneous wind speed and direction vary more widely than hourly averages.

The average hourly wind speed in Khartoum experiences significant seasonal variation over the course of the year. The windier part of the year lasts for 6.4 months, from October 29 to May 10, with average wind speeds of more than 15.9 kilometers per hour. The windiest day of the year is February 16, with an average hourly wind speed of 19.8 kilometers per hour. The calmer time of year lasts for 5.6 months, from May 10 to October 29. The calmest day of the year is October 1, with an average hourly wind speed of 11.9 kilometers per hour. 


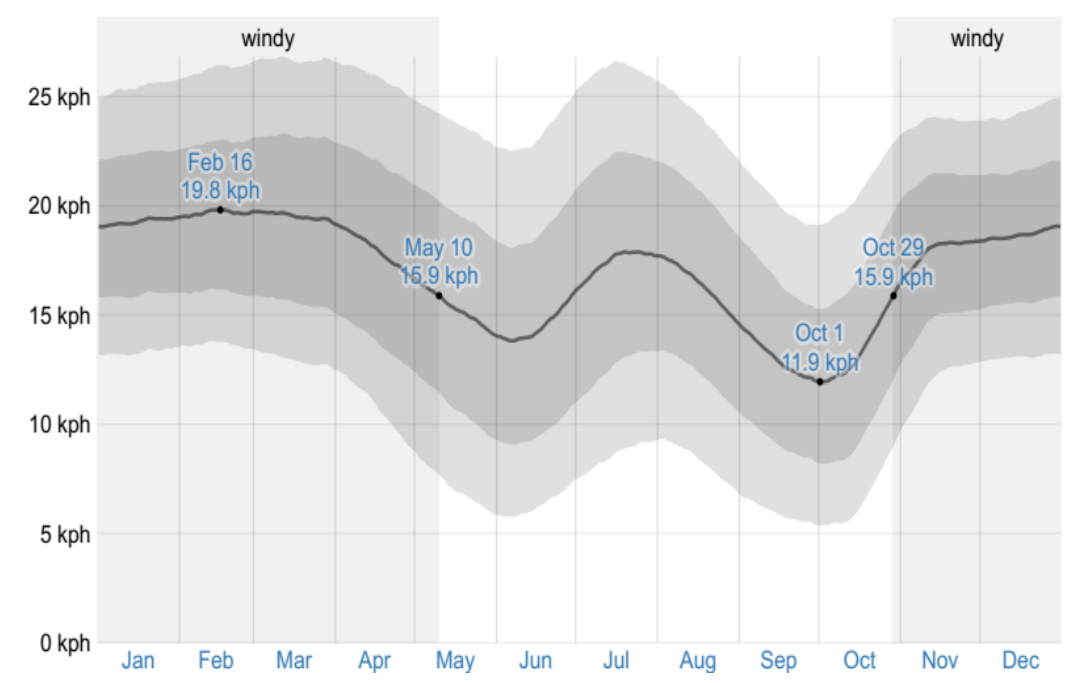

Figure (8): Average Wind Speed

The average of mean hourly wind speeds (dark gray line), with $25^{\text {th }}$ to $75^{\text {th }}$ and $10^{\text {th }}$ to $90^{\text {th }}$ percentile bands.

The predominant average hourly wind direction in Khartoum varies throughout the year.The wind is most often from the south for 3.9 months, from June 13 to October 10, with a peak percentage of $69 \%$ on August 8 . The wind is most often from the north for 8.1 months, from October 10 to June 13, with a peak percentage of $96 \%$ on January 1 .

\section{Wind Direction}

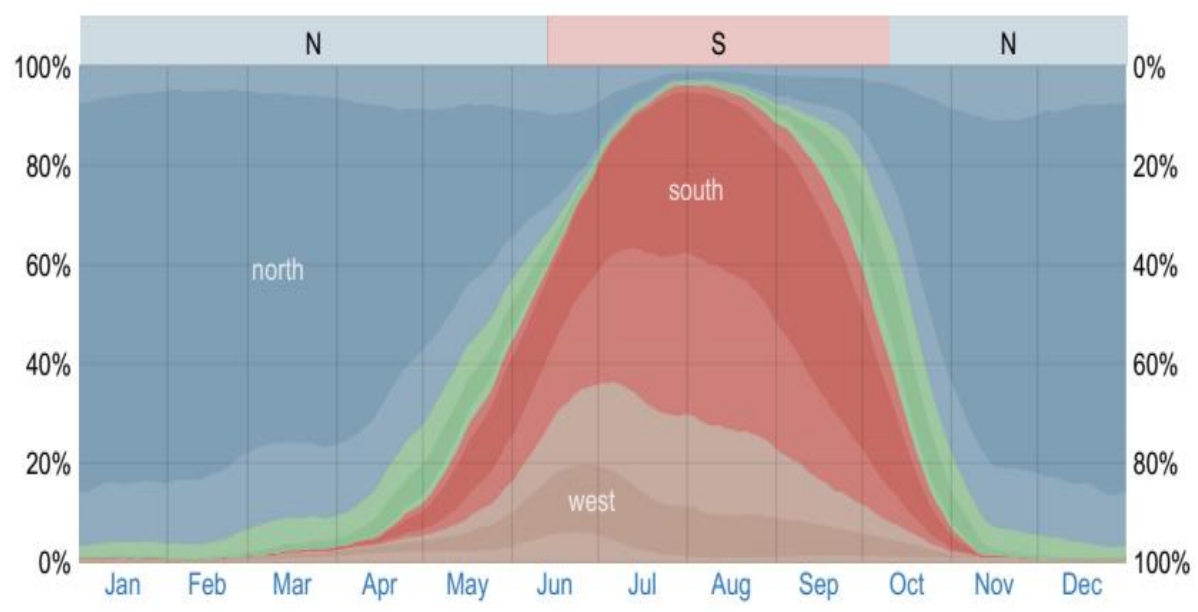

The percentage of hours in which the mean wind direction is from each of the four cardinal wind directions (north, east, south, and west), excluding hours in which the mean wind speed is less than $2 \mathrm{kph}$. The lightly tinted areas at the boundaries are the percentage of hours spent in the implied intermediate directions (northeast, southeast, southwest, and northwest). [17] 


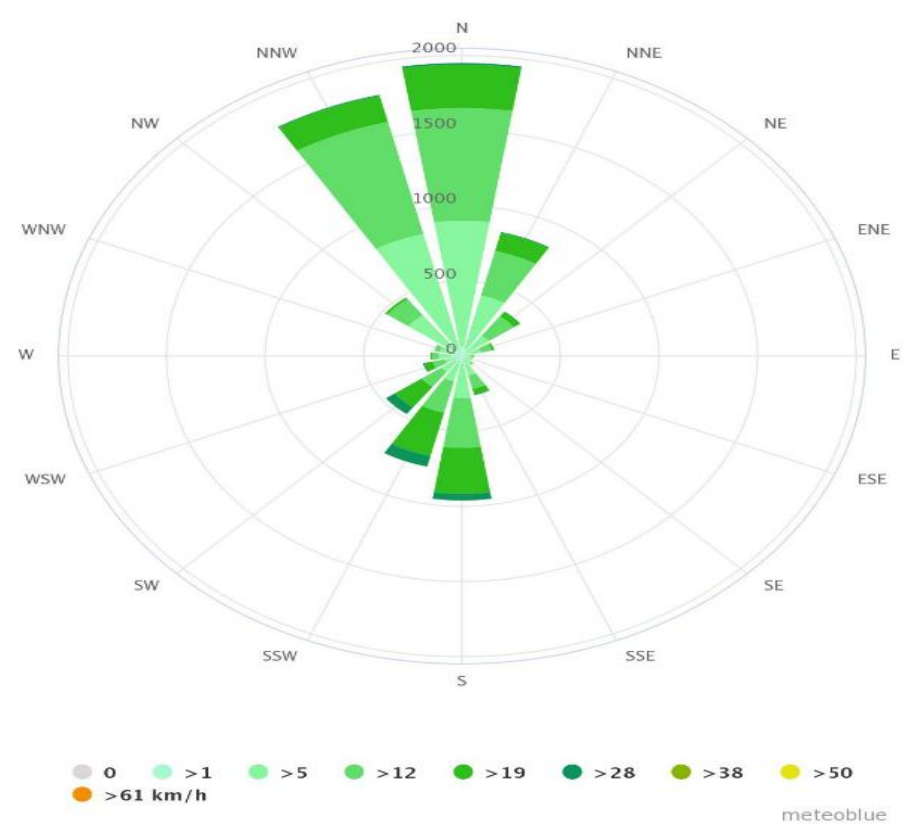

Figure (9): Khartoum Windrose Chart[18]

\section{Results:}

Spilled oil can reach groundwater bodies, in which case it will form a sheen on top of groundwater and will move at lower speeds.

Spilled oil starts evaporating when in contact with air (when it reaches the top of the water), and so the air above the spill becomes polluted with various volatile oil components. Depending on their concentration, such air pollutants may travel by the wind and aerosols.

The oil carried by rainwater in particulate matter forms may persist in the subsurface environments, including the top of groundwater, for decades.

The location of the petroleum liquid waste lagoon and their waste treatment/disposal is likely to be of interest to the surrounding community. The KRC should adequately inform neighbors on the nature of the proposal and the safeguards to be included, then seek community feedback and respond effectively to specific issues raised relating to the local environment, community health and social concerns, specially the current location for KRC was used as the residential area for Shaikh Othman village indigenous population.

As observed in the above aerial photographs, the lagoon areas in the KRC site is located next to the Southern border, and in the Eastern area of the Site near to the gate.

There was a spill of waste water appears in the second and third photographs and it was removed after March 2012, as shown in the aerial photograph of August 2013, but with no records showing the activities and scope of the soil and waste removal.

The green cover in the aerial photographs of August 2013 is more than the green cover of the aerial photographs before and after this period, the green cover has been increased due to the leakage and spill from the waste water lagoons.

The aerial photograph of September 2015 is showing that there was an overflow in the contaminated waste water lagoon and the waste water crossed the boundaries. The next aerial photograph showing that this overflow was dried by the normal evaporation. 
According to the aerial photograph of January 2016, there is an environmental hazard associated with the movement of the contaminated waste water, and the spill or the leakage or the overflow from the waste water lagoon has reached the natural water passage existing in the southern area of the KRC, and the result of the environmental hazard is shown as increasing in the green cover. The waste water by reaching this water course might reach the village and the River Nile and cause environmental impacts on the humans, agriculture and river Nile habitat. This environmental hazard appeared also in the aerial photograph of October 2016.

As shown in the model of the topographic map the study is surrounding with two valleys and the location of the waste water facility is in a critical area near to the southern valley, and the valley might be affected by the overflow from the wastewater area lagoon.

Also, the location of the KRC was not selected by putting into account the hazard and risk from the floods. And the area of the KRC is known for this risk and to the eastern area there is Wadi Alawatieb, one of the largest valleys at the surrounding area and its known for its flood risks in the rainy season.

The area of the KRC is semi-arid region and might be affected by a severe weather conditions in the rainy seasons, the rain is expected in the in the months of May, June, July, August, September, October and November.

Therefore, from the aerial photographs the area of the KRC is expected to be affected by the floods occurrence in the nearby valleys. And the affects might be from the overflow of the waste water area if the rain fall was more than the capacity of the disposal area. And it might be affected by the run offs in the above mentioned months.

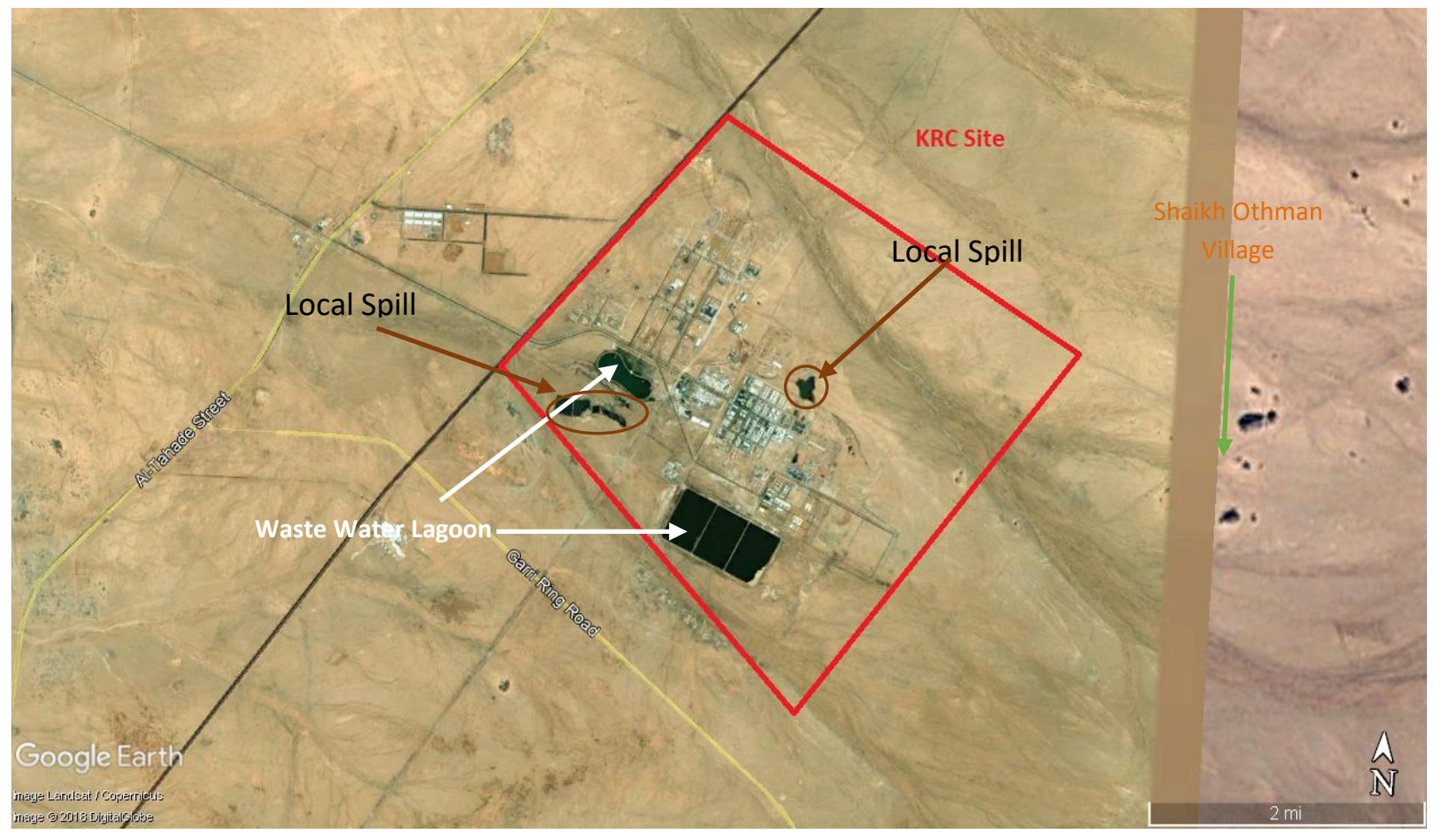

Aerial Photo 01: Aerial Photograph April 2004 


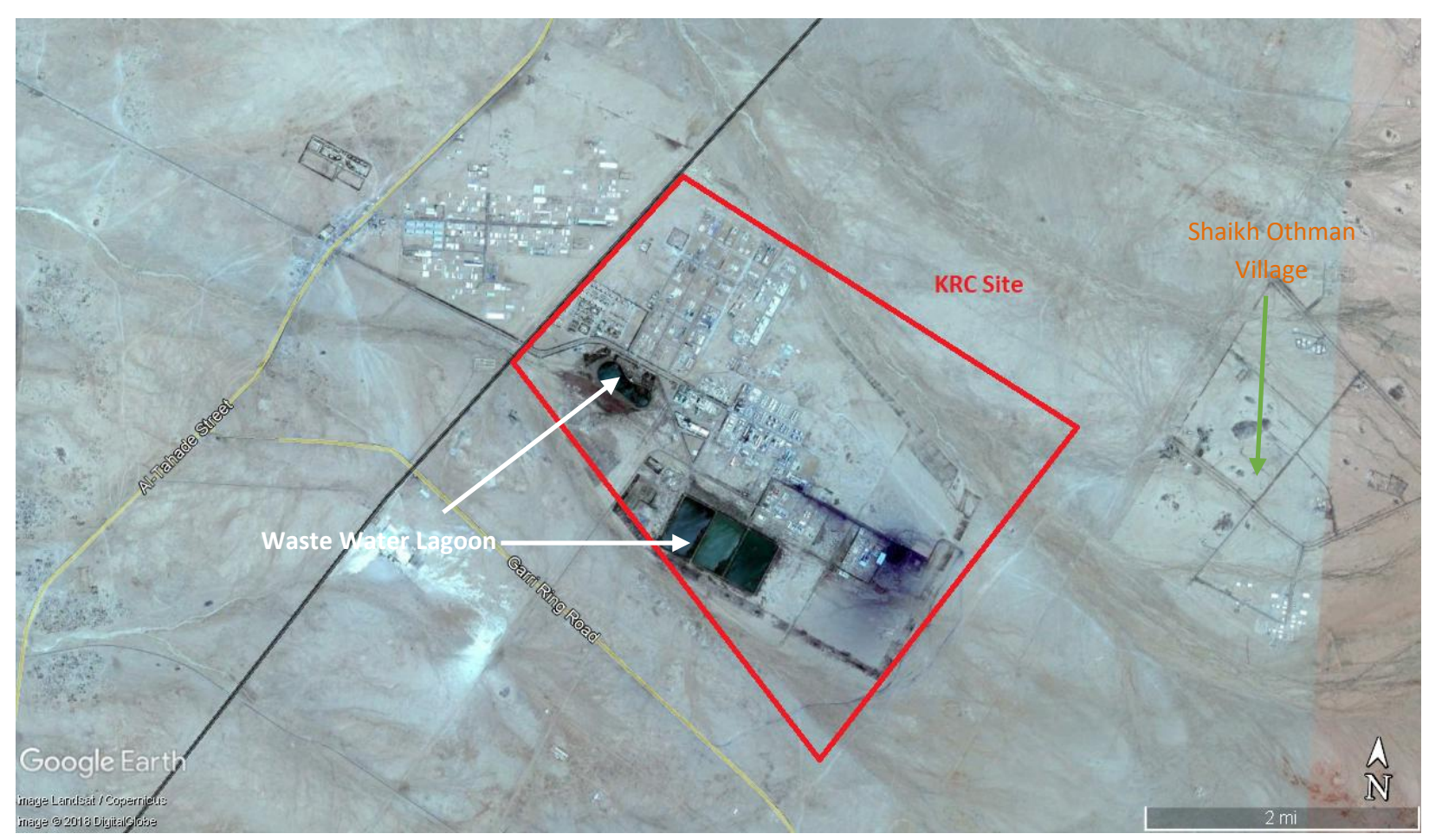

Aerial Photo 02: Aerial Photograph March 2014

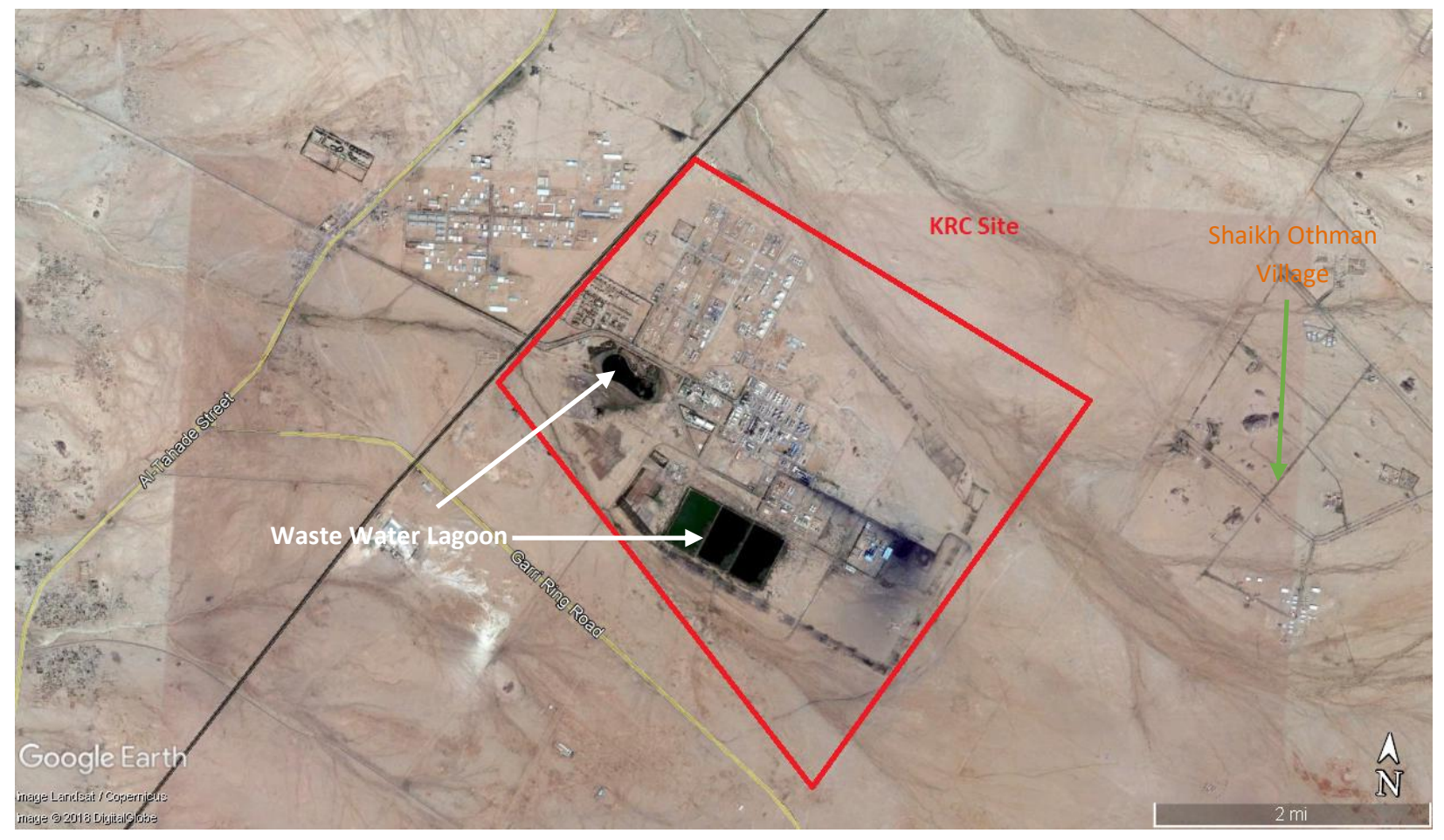

Aerial Photo 03: Aerial Photograph January 2015 


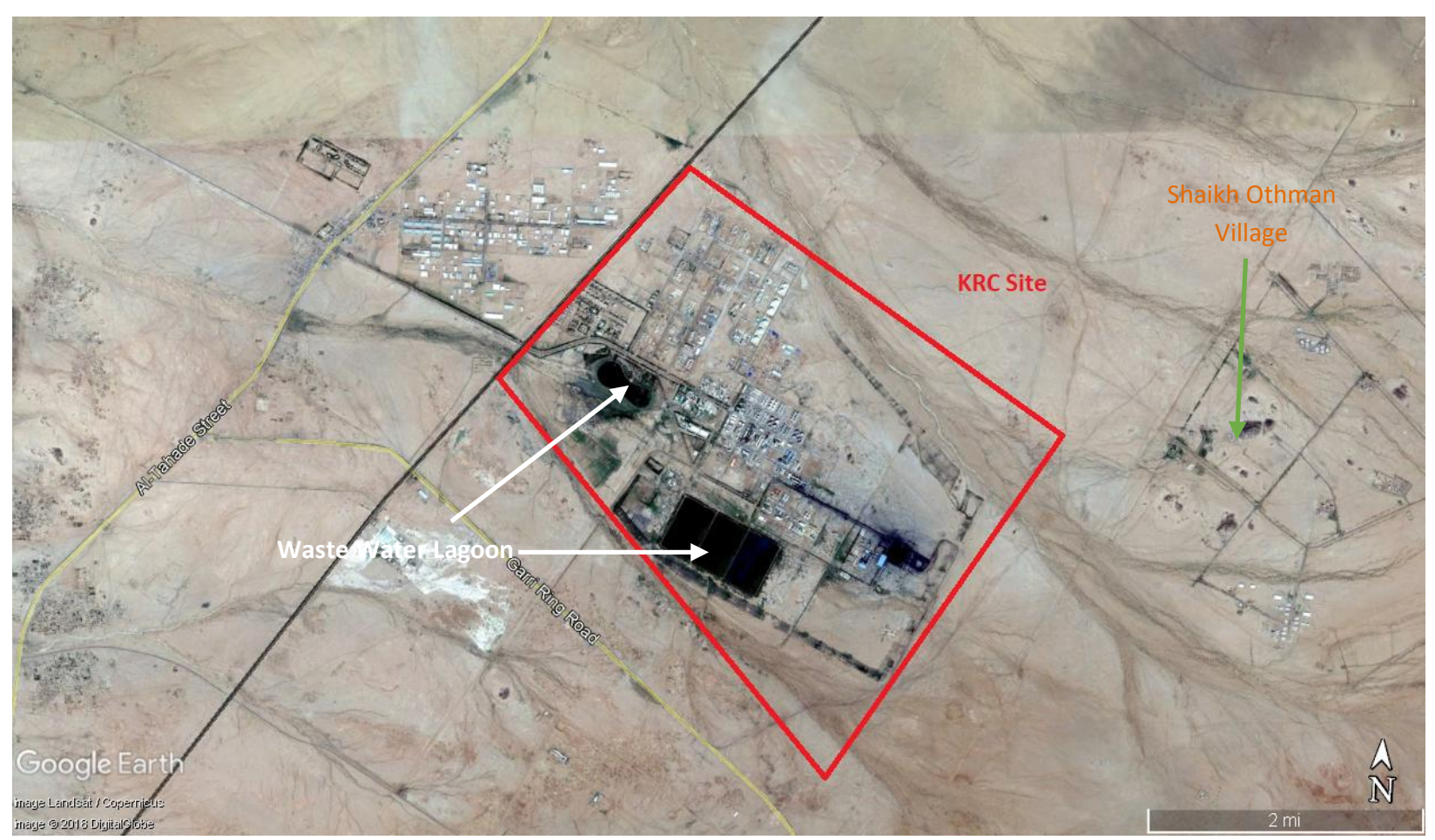

Photo 04: Aerial Photograph October 2015

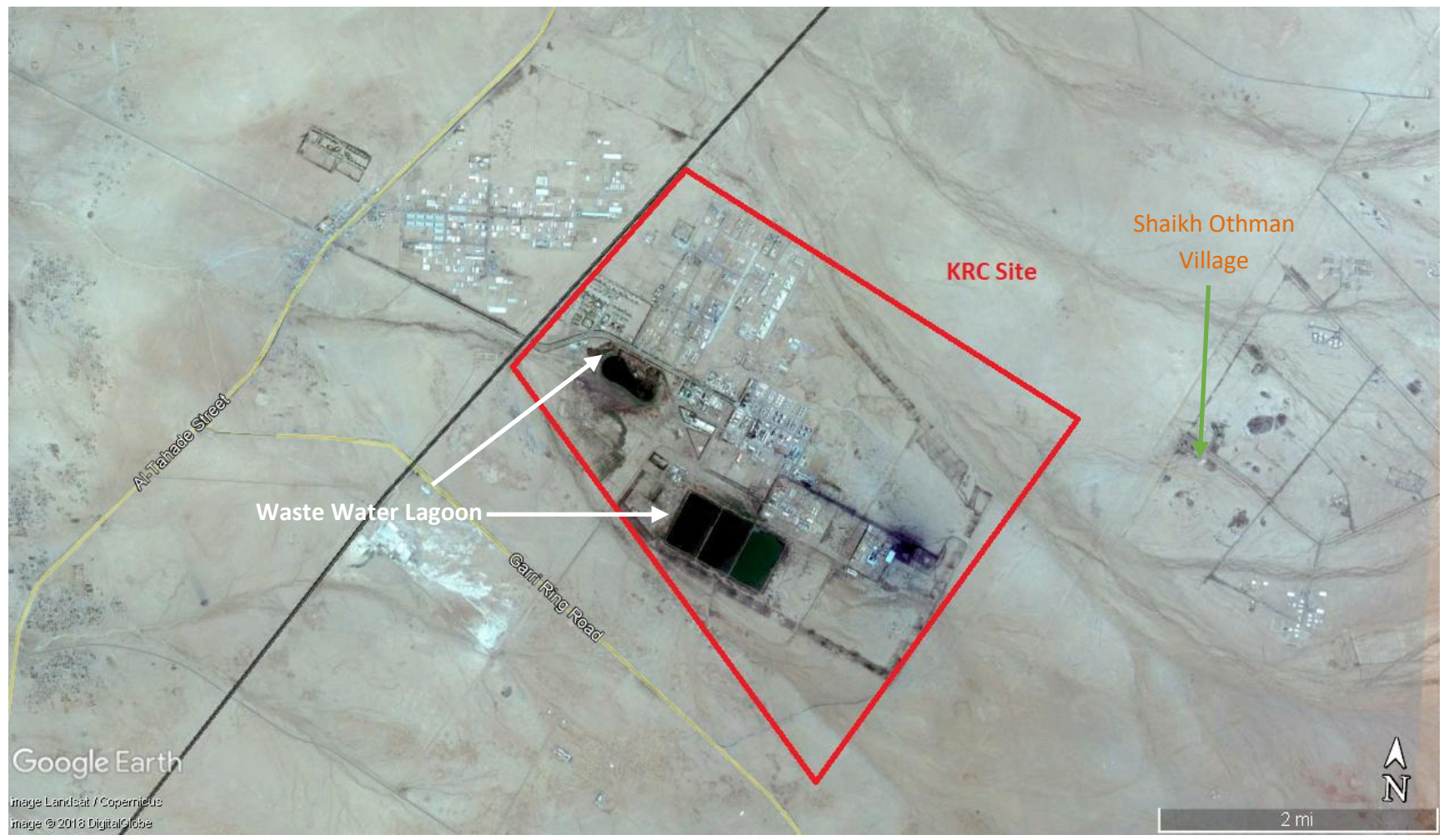

Aerial Photo 05: Aerial Photograph June 2016 


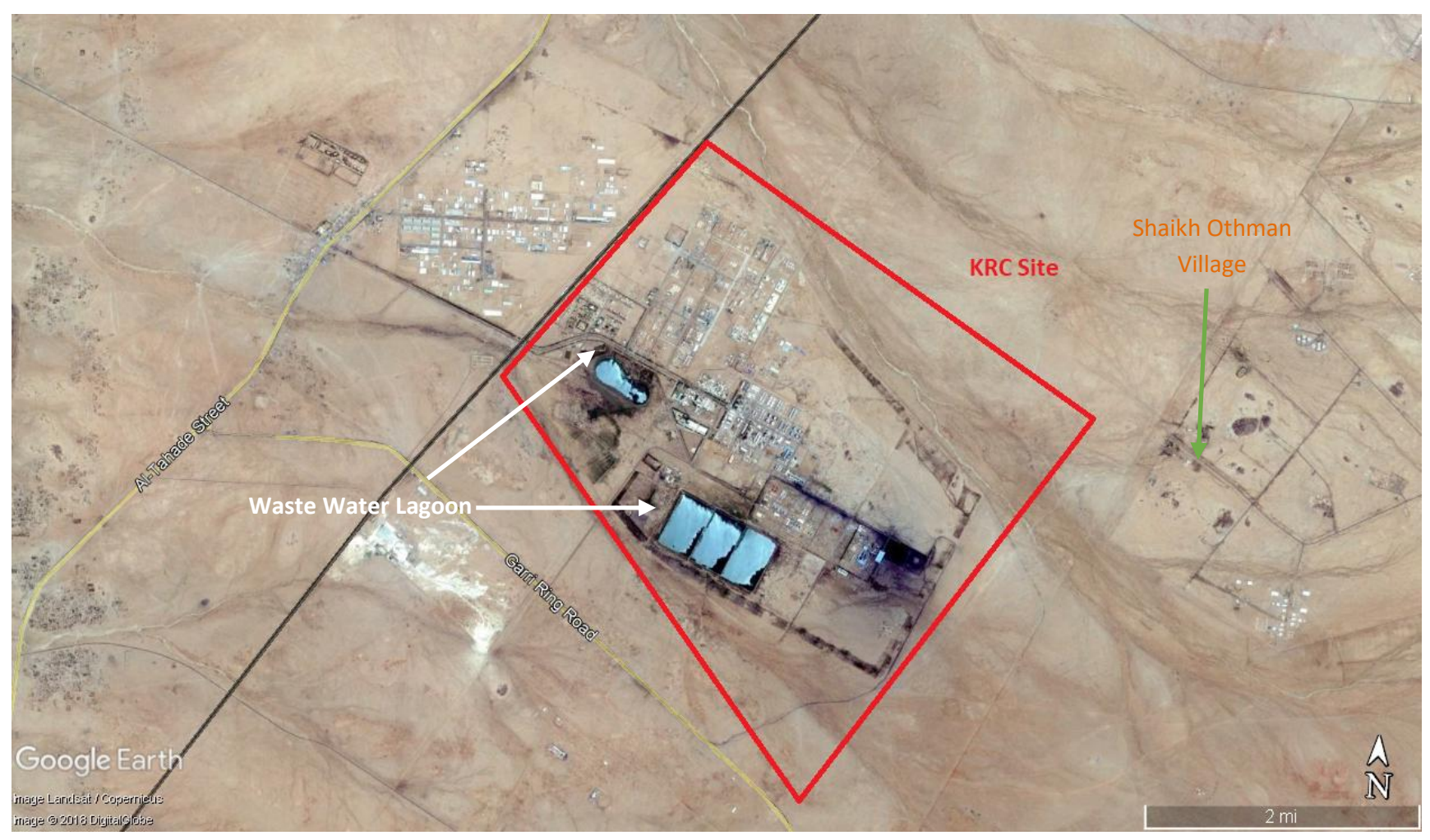

Aerial Photo 06: Aerial Photograph April 2017

\section{Conclusion:}

Petroleum refineries should manage storm-water runoff effectively, including in the vicinity of waste treatment and storage facilities, roofs, pavements, and exterior materials storage and process areas to avoid flooding or contamination of water resources.

Petroleum liquid waste and material used for its treatment and disposal may degrade water resource quality if released to the environment such as toxic chemicals. These should be stored and used within weatherproof, containment compounds.

These lagoons should be built using low permeability materials (such as concrete, rendered masonry, low permeability clay soil or synthetic liners). Surfaces should be chemically resistant or sealed to prevent damage by spilt chemicals. The compounds should be designed to allow recovery of any chemical spill, without discernible loss to the environment.

\section{Recommendations:}

- The site operator should prepare an emergency response plan to deal with events such as chemical spillage, natural disasters, fires, vandalism and equipment malfunctions. The plan should identify local water resources. It should provide management response protocols to limit the impact of foreseeable incidents. Designated employees should be trained in procedures to block chemical escape pathways and clean up spills. Site staff and contractors should be made aware of practices designed to the treatment of the wastewater.

- Site operators and designated staff should be trained to supervise the response to spill incidents and, if necessary, to liaise with emergency response personnel such as the civil defense Authority.

- Spill kits should be made available in easily accessible areas. They should include absorbent materials such as 'kitty litter', sawdust or rags and other clean up equipment such as mops, brooms and appropriate protective clothing. Hose-down of floor residues into drains should be avoided.

- Drain systems should be designed so that, in the event of large fluid spills, they can be isolated until the contaminant is recovered and removed. Drain plugs or sandbags should be labeled and located where they can be deployed quickly in an emergency. 
- Records and results of the monitoring program should be retained on-site for a minimum of two years for inspection or reporting and monitoring

- For further extension of KRC, it is recommended to ensures that environmental controls, transport corridors and servicing requirements are negotiated well in advance of development approval; so, the facility is suitably located, constructed, operated and maintained with an appropriate balance of environmental, as well as social and economic planning considerations.

- Detailed environmental monitoring plan EMP should be developed for the area, by drilling and constructing several environmental monitoring wells around the wastewater disposal area, and a program for sampling and analysis should be conducted every three months to evaluate the groundwater conditions and to ensure that there is no leakage from the disposal bonds. If the monitoring reports suggested that the groundwater is severely affected by the leakage of the contaminants from the wastewater disposal area, then an environmental assessment and remediation action plan should be developed and followed. In the above results for water analysis the copper is exceeding the limits of $\mathrm{RC}$, and the analysis of other contaminates is not available.

- The management of the KRC should adopt a benchmarking method and try to meet it, by adopting one of the international standards for environmental activities and take corrective actions for any breach on this standard. This should be adopted till the Sudanese authorities issue an environmental regulation detailing all the contaminants limits and monitoring requirements.

- There was no information about the construction specification of the KRC wastewater area, the study suggests that if the construction was done without considering putting liner before starting the activities then another wastewater pit should be constructed meeting the international standards and a remediation project should start immediately for the area of the wastewater, from the pictures in the study there is no evidence of constructing using liner materials.

- A remediation program for the generated sludge should be adopted by the KRC management to meet the zero-waste target for the wastewater area, the study suggests the use of bioremediation methods.

\section{References:}

[1] The Republic of Sudan: Bashayer El khair, Documentary Issue, Ministry of Energy, Khartoum, (2000).

[2] Laila Alhassan Obaidallah and Saif Elnas Abdelmagd; A Study on Liquid waste control measures practiced in Khartoum Refinery. Department of Chemistry, College of Science, University of Elneelain, Sudan, (2013).

[3] Elaine L. Chao, Secretary (2002): Occupational Safety and Health Admin. (OSHA) - U.S. Dept. of Labor,

[4] Sh. Ayatollah; journal of Petroleum Exploration and Production technology, vol.3, No.3 September, KACST, Riyadh, KSA, 2012

[5] Fang liu: "Pollution Treatment" the 1st Saudi Chinese forum, KACST, Riyadh, KSA, (28-29) October 2013

[6] Qatar Fertilizers Company- QAFCO: "Environmental Awareness", Doha, Qatar, 2009

[7] Abbas Mahmoud Awad (1985): "Psychology of Incidents", University Knowledge Press, Alexandaria, Egypt

[8] Khalid Ananza (2013): Ergonomics, Dorra Magazine No. 1643, Weekly Issue by Public Relations at Khafji Joint Operations, Saudia

[9] ExxonMobil Crisis Response Plan (2003): Environmental Health \& Safety Department Exxon Mobil Corporation, USA

[10] L W Burger \& M P Oberholzer : "Risk Assessment for The Proposed SUNRISE Energy Liquefied Petroleum Gas (LPG) Terminal at Saldanha Bay" -, Report No.: R/12/ERM-1B Rev 0.1, South Africa, 2012

[11] Terence P. Driscoll, Industrial Wastewater Management, Treatment, and Disposal Task Force, Industrial wastewater Management, Treatment and Disposal, USA, (2008).

[12] Government of Western Australia:Industrial Wastewater Management and Disposal, WQPN, Department of Water, October (2009).

[13] Lawrence K. Wang, Yung-Tse Hung,Nazih K. Shammas: Handbook of Environmental Engineering, Volume 5,AdvancedPhysicochemicalTreatment Technologies, USA, (2008).

[14] John Glasson, Riki Therivel: Introduction To Environmental Impact Assessment (Natural and Built Environment Series) 4th Edition, UK, (2012).

[15] Google Earth Program, Data SIO, NOAA, U.S Navy, NGA GEBCO Image Landsat/ Copernicus Image IBACO, USA, (2018).

[16] Main Control Center - Gaili Area: Sudanese Petroleum Corporation, Ministry of Petroleum, Khartoum, Sudan, (2016).

[17] https://weatherspark.com/y/97252/Average-Weather-in-Khartoum-Sudan-Year-Round

[18] https://www.meteoblue.com/en/weather/forecast/modelclimate/khartoum_sudan_379252 


\section{$\underline{\text { Annexure }}$}

$\underline{\text { Annex (1) }}$

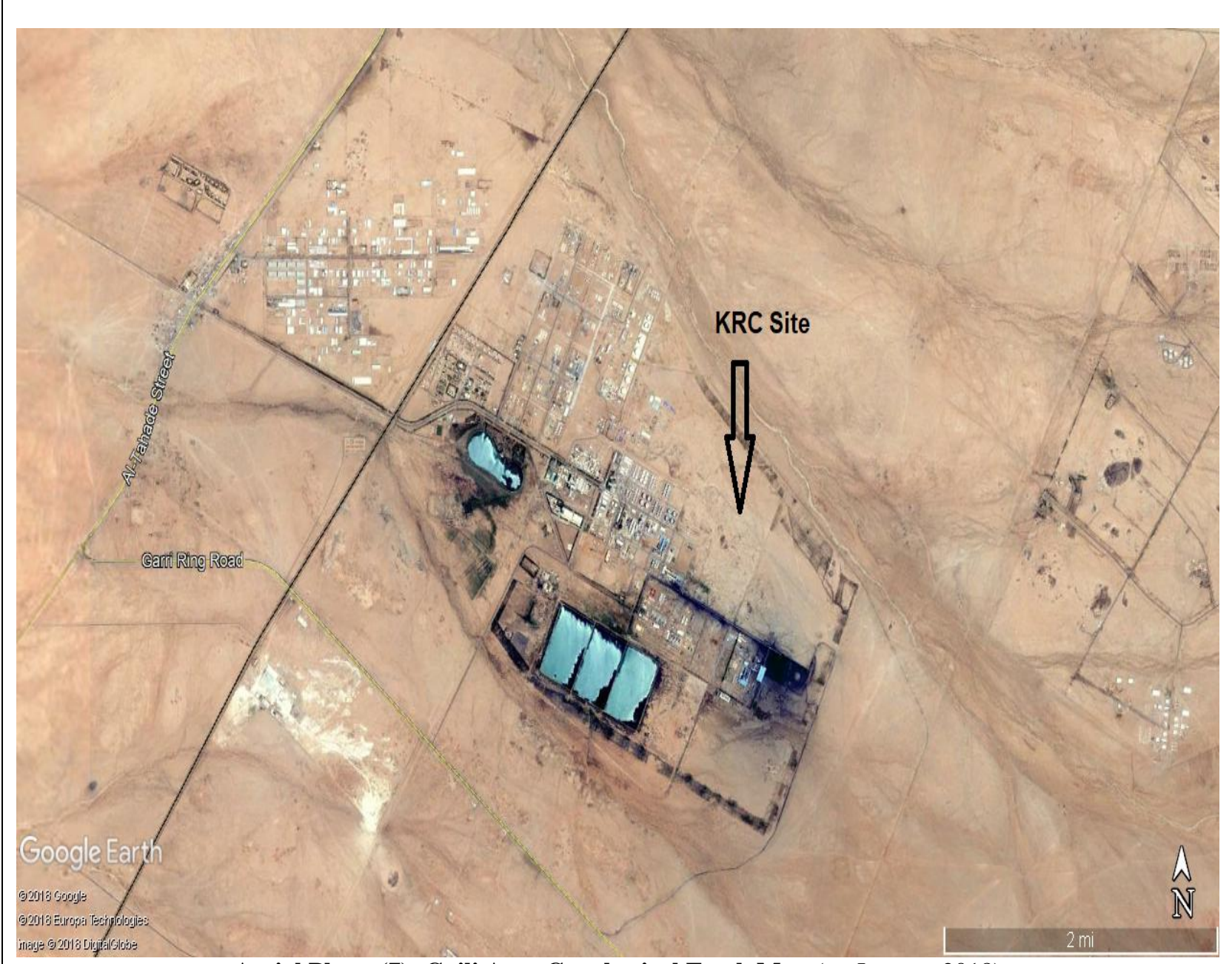

Aerial Photo (7): Gaili Area Geophysical Earth Map (on January 2018) 


\section{Annex (2)}

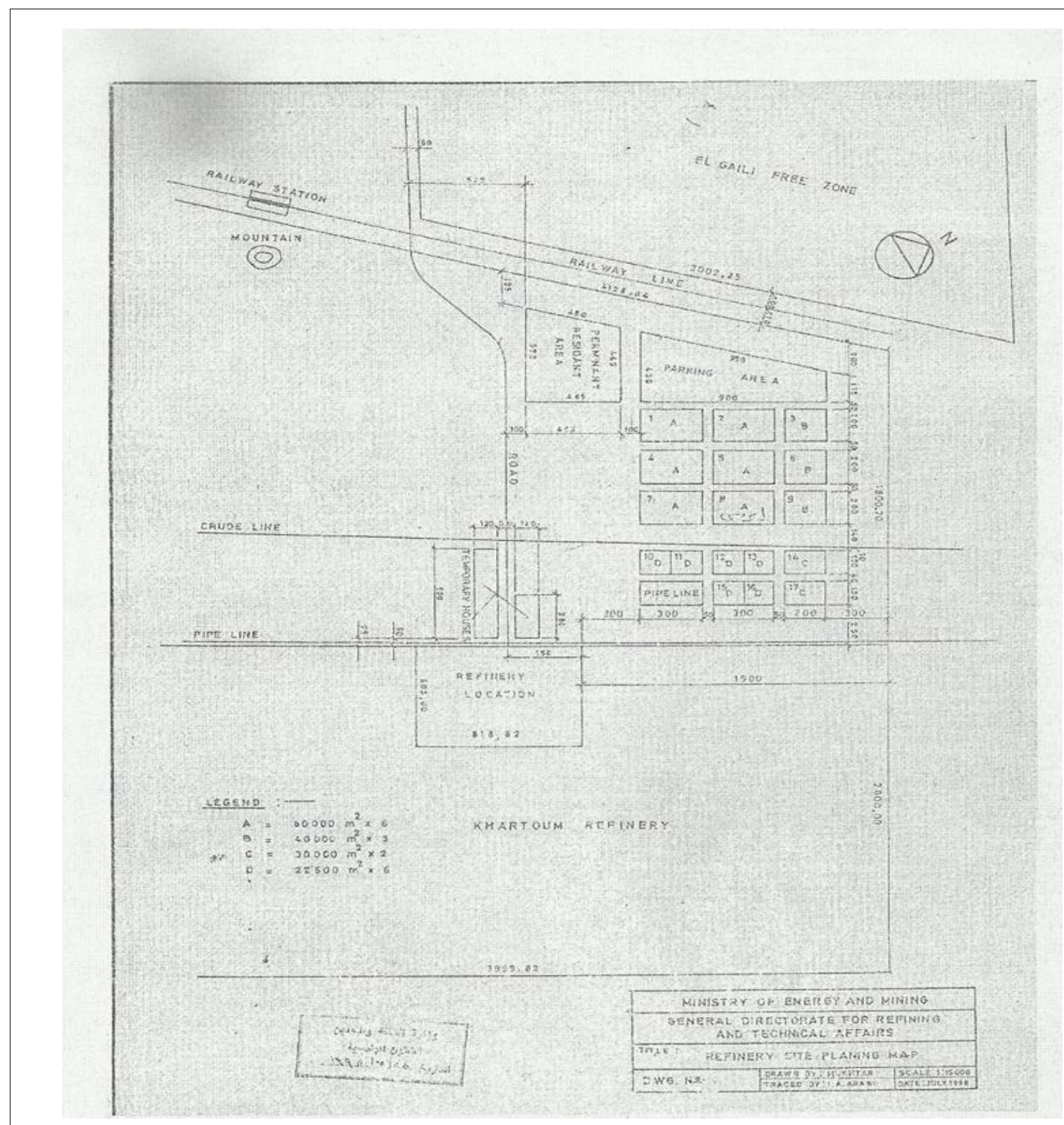

Figure (10): Gaili Fuel Terminals and Khartoum Refinery 